bers of the Official Committee for the preparation of a Draft for a new Civil Code, professors of different Universities, etc.

This is the fourth book on Law published by the Catholic University Press; the others are: "Universidad y Estudiante, Naturaleza Jurídica de la Relación Estudiantil: Hacia un Derecho Universitario" (24 pp., 1976, US \$8), by Dr. Rogelio Llerena; "Derecho y Desarrollo. Perspectiva de Análisis" (172 pp., 1978, US \$9), by Dr. Lorenzo Zolezzi; "El Nuevo Derecho del Mar. El Perú y las 200 millas” (465 pp., 1979, US \$23), by Dr. Eduardo Ferrero.

Those books can be ordered directly from Fondo Editorial de la Universidad Católica. P.O. Box 1761, Lima, Perú.

\title{
MEETING OF GERMAN LAW LIBRARIANS
}

Members of the Association for Law Librarianship and Documentation in the German-speaking countries (Arbeitsgemeinschaft für juristisches Bibliotheks-und Dokumentationswesen-AjBD) held their annual meetin Wuppertal (F.R. of Germany) on May 29, 1980, in conjunction with the German Librarians Congress. Mrs. Claire Germain from Duke University Law School in Durham, N.C., Visiting Foreign Law Librarian at the Max-Planck-Institute in Hamburg in May and June 1980, took part in this conference as a guest. A new Board of Directors of $\mathrm{AjBD}$ was elected for the period 1980-82:

Chairman: Dr. Raimund-Ekkehard Walter, Staatsbibliothek Preussischer Kulturbesitz, Berlin; Vice-Chairman: Dr. Renate Bellmann, Dusslingen; Secretary: Veronika Götz, Bibliothek der Hochschule für Verwaltungswissenschaften, Speyer ; Treasurer : Dietrich Pannier, Bibliothek des Bundesgerichtshofes, Karlsruhe; Managing Editor of the "Arbeitshefte": Dr. Ralph Lansky, Bibliothek des Max-PlanckInstituts für ausländisches und internationales Privatrecht, Hamburg; Managing Editor of the "Mitteilungen": Dr. Hans-Burkard Meyer, Universitätsbibliothek Augsburg; Additional members of the Board: Joachim Schwietzke, Bibliothek des Max-Planck-Institutus für ausländisches öffentliches Recht und Völkerrecht, Heidelberg; Dr. HansPeter Ziegler, Universitätsbibliothek Würzburg.

Dr. Ralph Lansky

\section{EXCHANGE OF PERSONNEL}

At their February meeting, the Executive Board of the American Association of Law Libraries approved widening the scope of the Special 